Articles

Winter 2001

\title{
The Qur'ân in Indonesian Daily Life: The Public Project of Musical Oratory
}

Anne K. Rasmussen

College of William and Mary, akrasm@wm.edu

Follow this and additional works at: https://scholarworks.wm.edu/articles

Part of the Ethnomusicology Commons

\section{Recommended Citation}

Rasmussen, Anne K. "The Qur'ân in Indonesian Daily Life: The Public Project of Musical Oratory." Ethnomusicology 45, no. 1 (2001): 30-57. 


\title{
The Qur'ân in Indonesian Daily Life: The Public Project of Musical Oratory
}

\author{
ANNE K. RASMUSSEN / College of William and Mary
}

I

n Indonesia, amidst a plethora of unique Southeast Asian popular and folk music, Western music, and traditional gamelan styles, the recitation of the Qur'ân pervades daily life as an archetype of Muslim authenticity. Removed by thousands of miles and hundreds of years from the source of Islam, Indonesians perform and experience the Qur'ân in allegedly the same way as Muslims did during the time of the prophet, Muhammad. This article distills eight months of research as a student of professional male and female reciters of the Qur'ân in Jakarta, Indonesia, the capital city of the country that is home to more Muslims than any other in the world. It is a work in progress that foregrounds issues pertaining to: historical process; music learning, conceptualization, and performance; the role of ritual specialists in a community; the social construction of gender roles; and the congruence of political ideology and religious practice in contemporary Indonesia. ${ }^{1}$ How has the system of Arab musical modes that are employed for religious performance, been transmitted and perpetuated in Indonesia for nearly 400 years? What are the roles of professional male and female reciters (Qari' and Qari'ab) as they enable the continuity, through space and time, of this religious art? Why in Indonesia are women-school girls to national champions-participants in the public project of recitation when in the global Islamic umma (community) women's participation in religious life is often segregated and limited to the private domain? How has the project of New Order nationalism served to support and create social and cultural structures that officially institutionalize the recitation of the Qur'ân, and how will the dynamic current of Reformasi (Reformation) effect this support? Each aspect of the investigation is seasoned with and limited by my own experiences as they were lived in the course of my work with those in Jakarta who practice seni baca al-Qur'ân, the art of reciting the Qur'ân.

(C) 2001 by the Board of Trustees of the University of Illinois 


\section{The Ethnographic Setting}

A good deal of my ethnographic work took place at the Institut Ilmu al-Qur'ân (Arabic: 'Ilm al-Qur'ân), The Institute for the Study (or more literally, "Science") of the Qur'ân, a college for women in south Jakarta. On my first two visits I had caused something of a stir. After just a few minutes of instruction from our teacher, the recitation class had dissolved into a "show and tell with Ibu Anne." 2 The rigors of learning religious songs, called tawâshîh had been suspended at the direction of our guru (teacher); I was asked to come to the front of the class and talk about myself. Part of my "life story" for the class consisted of a little lecture demonstration on Arab music. I played the Arab lute, the 'ûd, ${ }^{3}$ and sang songs in the Arabic language. I tried to explain how Arab music works and why it is related to the recitation of the Qur'ân in Jakarta. ${ }^{4}$ Through my performance, I aimed to satisfy their curiosity with regard to my motivation for studying seni baca al-Qur'ân. ${ }^{5}$

Following an indication from our guru, Haji Moersjied Qari' Indra, for my third visit to the Institute I had equipped myself with my first busana Muslim (Muslim fashion) outfit, complete with matching jilbab (head covering). My new Muslim fashion was greeted with unveiled enthusiasm. "Oh cantik, cantik" (beautiful, beautiful) the class chorused-"how nice you look in busana Muslim" (busana Muslim cocok)—"Why you look just like one of those Bosnian women on T.V." (seperti wanita Bosnia) one woman commented. At this point I was finally permitted to just sit and participate with the girls in the class as we imitated, in full singing voice, our guru line by line, phrase by phrase, in the music of the Qur'ân.

The opportunity to live for a year Indonesia arose when my husband was appointed advisor to the Indonesian Ministry of Environment. When my Dean approved my leave of absence I began to contemplate how I might go about studying the recitation of the Qur'ân. I hoped that my concentration for the past ten years on Arab music as a "first" area, through graduate studies, teaching, and performance, would give me a framework appropriate for research on this topic. I was curious about how the Qur'ân was learned and experienced in the non-Arab context of Indonesia. Qur'anic recitation in Jakarta sounded "Arab" I thought, as I identified strains of maqâmât (Arab modes) emanating from our neighborhood mosques or from our car radio. I was plagued by an urge to discover whether Indonesian reciters talked about the vocal artistry of the Qur'ân as "Arab music." What terminology did they use? How was musical practice described, articulated, conceptualized? ${ }^{6}$

A chance meeting in November, 1995 with one of the judges at a competition for call to prayer (adzân), held at the month-long, governmentsponsored, Islamic Festival Istiqlâl led to an invitation to the Insitut Ilmu 
al-Qur'ân (IIQ). For the next eight months until my departure from Indonesia in July 1996, I attended weekly class and small group and private lessons at IIQ, an all female college dedicated to Qur'ânic studies. I engaged in formal interviews and conversations with the director (Kiyai Haji Ibrahim Hosen), with IIQ faculty, and Kiyai Haji Sayyid Mohammad Assirry, one of the premier reciters in Jakarta. I met reciters and scholars who visited from elsewhere in the Islamic Diaspora (i.e. Malaysia, Iran). I accompanied my two main teachers, one male (Drs. H. Moersjied Qari' Indra) and one female (Qari'ah Hajjah Maria Ulfah, M.A.), to many of their engagements. These teachers are in high demand as professional reciters in contexts that vary from official government events to the nightly evening-long prayers held during the month of Ramadan. Furthermore, Qari' Moersjied and Qari'ah Maria are called upon regularly to judge the myriad competitions in Qur'anic recitation, Musabaqab Tilawatil Qur'ân (Musâbaqat Tilawat al-Qur'ân ) - MTQ, that are held in every corner of Indonesian society, from neighborhood mosque to government ministry to national television studio. I also spent several days as a guest of Moersjied's family in residence at a Pondok Pesantren (religious boarding school) in South Sumatra. My visit coincided with their annual graduation ceremonies as well as with the inauguration of a government program that attempts to combine the efforts of the local military with the needs of Islamic boarding schools (ABRI Masuk Pondok Pesantren-literally, "The Army Enters the Islamic Boarding School"). By the end of my first residence in Indonesia, my interest in studying seni baca al-Qur'ân had blossomed into a full schedule of classes, lessons, interviews, excursions, and invitations to competitions and evening activities.

\section{The Transmission of the Qur'ân in Indonesia}

Since the arrival of Islam in Indonesia, Indonesian Muslims have been learning to recite the Qur'ân, and to sing other religious musical genres with the language, melodies, rhythms, timbres, and musical aesthetics of the Arab world. Transmitted orally, at first through pilgrims and religious teachers beginning in the sixteenth century, this musical system is still largely an oral tradition. Today the tools of music media, radio, cassettes, television, and videos assist in this transmission process. Although they are products of latetwentieth century technology, these instruments of mass media, rather than eclipsing the traditional process of learning as it was established during early Islam, merely extend and enhance the process of oral transmission. Thus, in consort with the teaching devices technology offers-from didactic commercial cassettes that take you phrase by phrase through the musical and modal stylings of recitation, to call-in radio shows where amateurs 
perform a reading of their choice on the air that is then critiqued by a specialist-it is still the professional reciters of Indonesia who bear a great deal of the responsibility of teaching, performing, and preserving the Qur'ân in the form that, according to Muslim belief, it was given to the Prophet Muhammad over the course of twenty years until his death in the year 632 .

The orality of the Qur'ân is central to its authority as the divine word of God. ${ }^{7}$ In her discussion of the relationship between the oral revelation and the written text, Kristina Nelson asserts that the written text, compiled by Caliph "Uthman, the third successor of Muhammad, did "not exist to preserve against change; it is taken for granted that oral tradition does that" (preserve the Qur'ân against change) (Nelson 1985:3). Nelson elaborates further that Muhammad spread his divine message "by sending out reciters, not texts" (ibid). Revealed in the Arabic language, Muhammad, rather than just thinking the verses of the Qur'ân or reading them on a tablet, recited them at the command of Gabriel whose words were "Iqra' bi-smi rabbika" - "Recite in the name of your/thy Lord!" (Qur'ân 96/1) (ibid.:1; Sells 1998:7). In Jakarta, Qari' Moersjied elaborated upon the way in which such recitation should take shape: "Iqra' al-Qur'ân bi-al-alhan al-Arab," he recounted in Arabic in class and conversation; "Bacalab al-Qur'ân dengan lagu Arab," he translated, "read the Qur'ân with Arab melodies or tunes." 8

Qari' Moersjied taught "lagu Arab"-Arab melodies-according to what seems to be a fairly well codified system in Jakarta. Specific tawashîh, religious songs, are sung to particular Arab modes. Each line of text, corresponds to a melodic phrase that is rendered vocally and in free rhythm. Taken together, the melodic phrases that correspond to each line of a tawashîh text feature the notes, directional tendencies, and characteristic musical gestures, shapes, and ornaments of a particular Arab musical mode or maqâm, for example maqâm Bayâtî, or maqâm Ṣabâ.

Arâ tayran 'ala ghusni yunadi Atat busrâ̂ li majrubi fu'adi Bada Laylâ fa-adbâ 'ashiqubâ Rukû'an sujadan fi kulli wâdi
I see a bird calling from my bough Good news to a lover wounded in heart! Layla has appeared and her lovers Are head to the ground in worship in every valley

In my experience of learning recitation in Jakarta, the correspondence of musical lines that professional reciters there taught me to the musical material I had learned as a student of Arab music were surprising. Yet these reciters exhibit little recourse or reference to the concepts or language of musical theory - the way in which musicians explain what music does. Rather, through a lifetime of repetition, practice, and memorization, Indonesian reciters embody the patterns of Arab music and share them among 
Example 1. Tawâshîh "Arâ Ṭairân," Maqâm Șabâ (translation and transliteration from the Arabic by Michael Sells)

Tawashị Saba
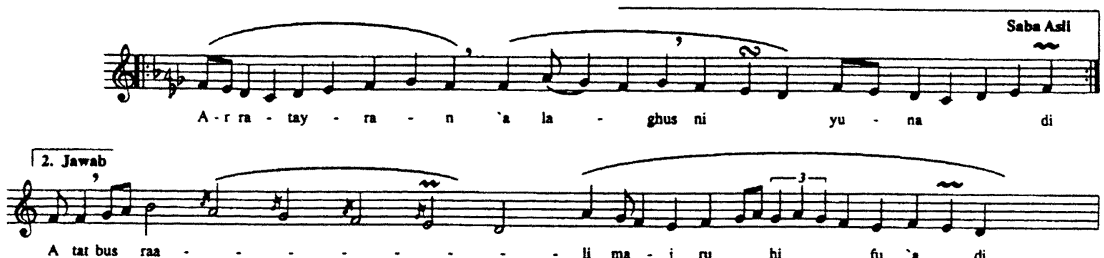

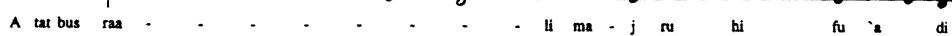
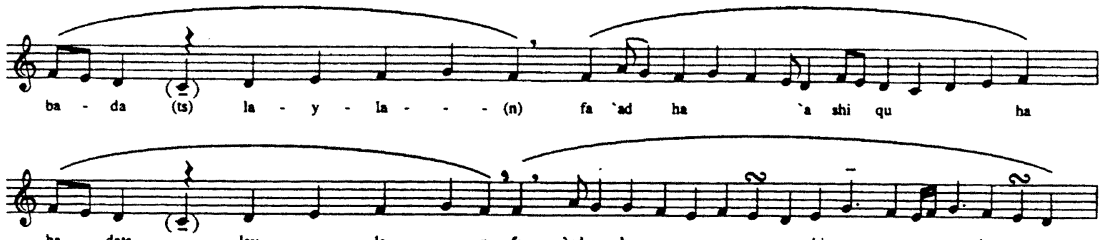

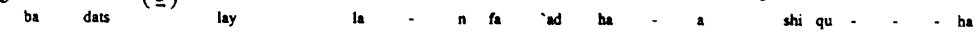

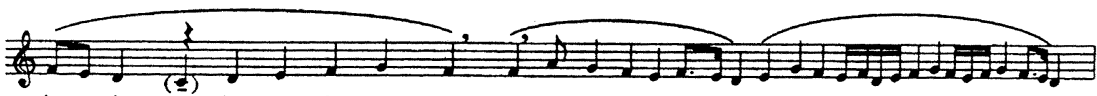

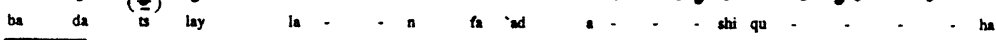
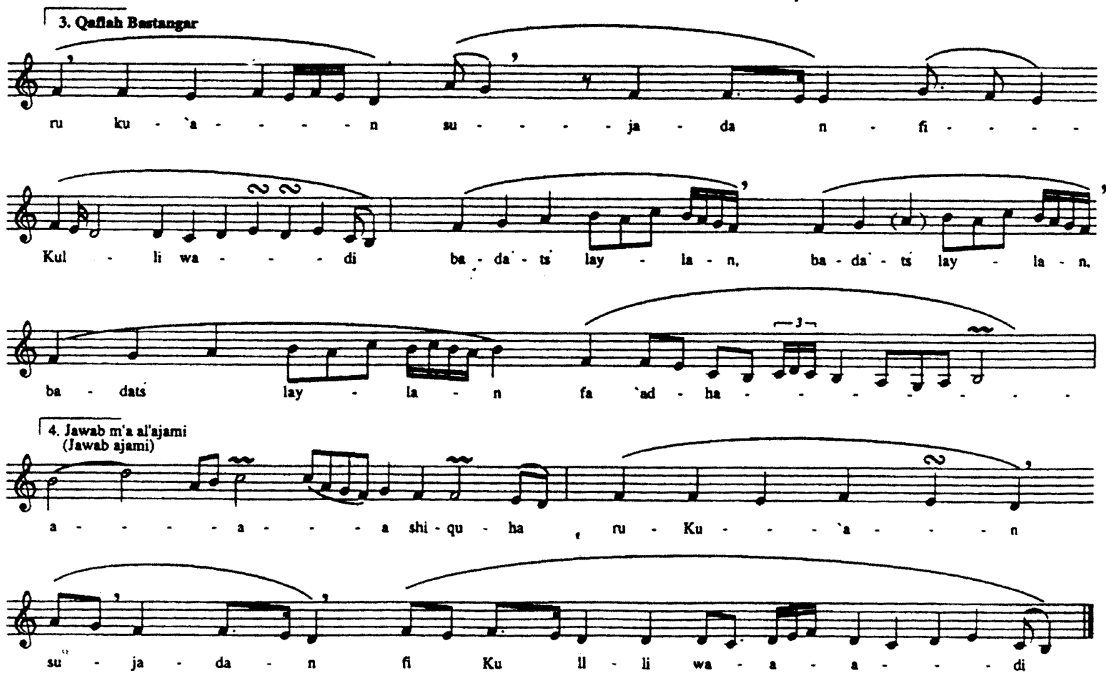

themselves and their students through a process that ethnomusicologist Kyra Gaunt, in her study of African American children's game songs, has termed "oral kinetic etudes."

In addition to just "getting the notes and the Arabic pronunciation right," Qari' Moersjied implored his classes on more than one occasion io 
infuse their singing with "Arab soul" (Arabic: rûh, Indonesian: jiwa). Throughout his delightful classes, often full of joking and laughter, Qari' Moersjied would urge his students not just to listen to his commercially released cassettes but, more importantly, to listen to the "great singers from the Arab world: Umm Kulthûm, Fayrûz, Warda," the list went on. "This is the music of the Qur'ân," he insisted, although he admitted in later conversation that although the music was the same the application (aplikasi) was different (Moersjied, interview March 5, 1996).

Such a comparison-between music and the vocal artistry demanded by the mujawwad style of recitation (a public, more demonstrative and musical style) - would, arguably, be unheard of in the Arab world, where, as Nelson writes, "Muslim religious authority insists that, by definition, the tradition of Qur'ânic recitation must be kept distinct from music" (1985:xiv). She continues:

This perception is based on the divine nature of the text. The parameters of rhythm, timbre, and phonetics are all perceived as having a divine source and organization in that they preserve the sound of the revelation as it was transmitted to the Prophet Muhammad. Moreover, the divine identity of the text gives it an inherent perfection and makes of it a model of beauty, while imbuing it with an authority and prestige that distinguish it from music. To label

Figure 1. The reciter and teacher Qari' Moersjied taking roll during a class at IIQ.

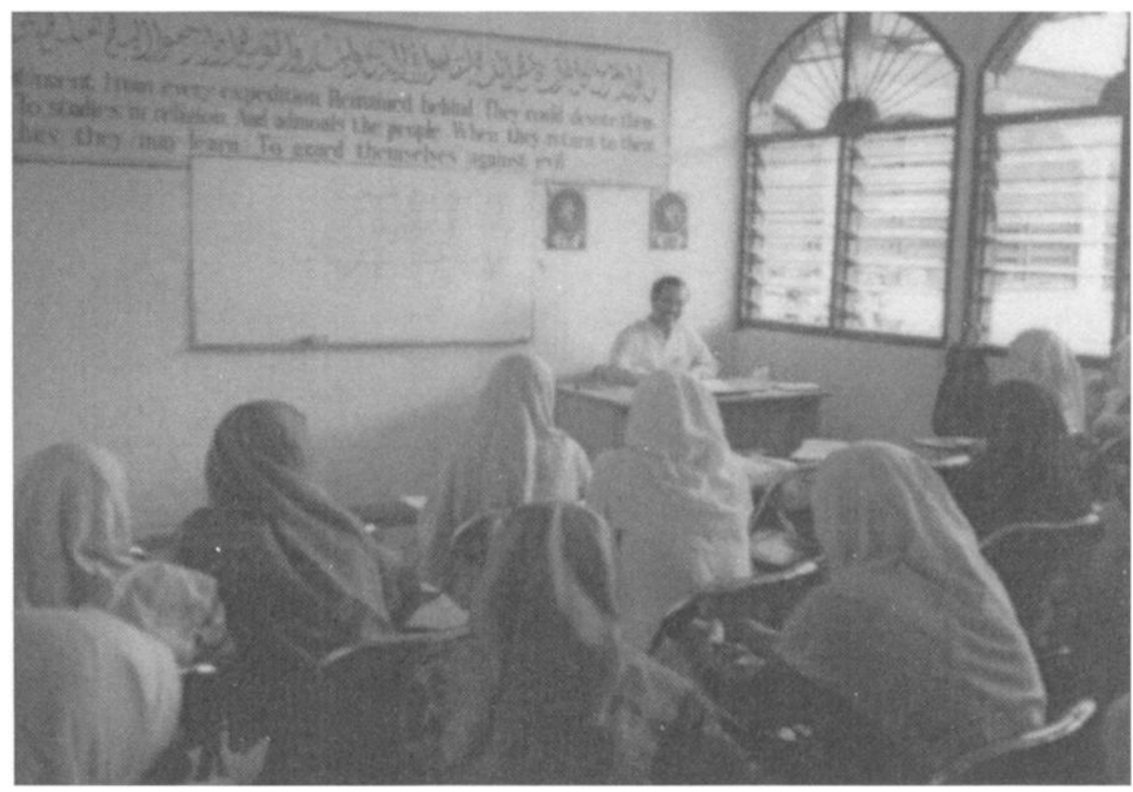


Qur'anic recitation as music undermines the perfection and uniqueness of the text, trivializing its effect on listeners and reducing it to the status of entertainment. (ibid.:xv)

In the Arab context, particularly Egypt, the conference of rhetoric and cultural practice is complex. Although recitation is never to be confused with music, reciters may study the Arab musical modal system, or maqâmât, perhaps even in the context of a music conservatory. Reciprocally, the vocal artistry of professional singers is enhanced when they study recitation, simply because of the many aspects of performance practice-melody, improvisation, ornamentation, phrasing, breath control, and pronunciationdemanded by both good singing and good recitation (ibid.: Ch. 3). In spite of various historic controversies surrounding the inappropriate use of music, something Nelson refers to as the "Sama' Polemic," there seems to be an understanding in some parts of the Arab world about the reciprocity between good singing and good recitation. Virginia Danielson in her authoritative and captivating study of Umm Kulthûm, perhaps the most famous singer of the twentieth-century Arab world, writes: "When Egyptians talked about Umm Kulthûm they often said 'She was good because she could recite the Qur'ân'" (Danielson 1977:10).

How, in the case of Indonesia, could one account for an apparent lack of the "Sama' Polemic," the debate on music and its permissibility? I suggest that it may be because music performance as it exists in Arab culture, with its prominent (and, for conservative critics, controversial) performeraudience dynamics, is not a part of Indonesian life. In Jakarta, concerts of Arab music (baflât) where audience members, overpowered by the performance of a great singer, swoon, sway, dance, and call out exclamations of enthusiastic approval and self-indulgent participation, are rare. Great Arab performers do not tour Indonesia, and the aesthetics of kayf, saltanab, and tarab, all Arab terms having to do with the enchanting power of music to drive one to ecstasy, do not seem to be part of Indonesian musical and aesthetic discourse. Indonesian musics, including the many kinds of Islamic popular and folk musics, and the demeanor of Indonesian audiences are very different from those found in the Arab world, and it is perhaps for this reason that the comparison of recitation with music is simply not the issue of grandeur that it might be in an Arab context. In fact, although I was there to study the recitation of the Qur'ân, discussing, playing, and singing Arab music formed a substantial portion of the discourse among myself and the students and faculty at the IIQ. ${ }^{10}$

\section{Women's Voices}

The women's college Insitut Ilmu al-Qur'ân was founded in 1977 by current director Kiyai Haji Ibrahim Hosen who like many Islamic scholars, 
did the core of his training in Cairo, Egypt at Al-Azhar University, the premier university of Islamic learning in the world. IIQ, as it is called in Jakarta, is modeled after a similar Institute for young men also founded by Hosen in 1971, the Perguruan Tinnggi Ilmu al-Qur'ân, PTIQ (High Insitute for the Science [study] of the Qur'ân). IIQ trains hundreds of young women in Qur'anic studies which include tajwîd (the system which codifies the divine language and accent of Qur'anic recitation in terms of rhythm, timbre, the sectioning of the text, enunciation, and phonetics), tafsir (commentary and interpretation), Arabic, sharì $a$ (Islamic law), and nagham (the melodic aspects of Qur'anic recitation). Students at IIQ also take "regular" university courses such as psychology, Pancasila (Indonesian Civics), and English. IIQ combines University curriculum with the teaching and lifestyle of the Pondok Pesantren (Islamic boarding school); young women live in an asrama or dormitory where extra curricular activities surrounding Qur'anic studies may occur, for example, memorization classes.

Both Institutes, the IIQ for young women and the PTIQ for young men, are products of post-independence, New Order Indonesia, ${ }^{11}$ a political and cultural era that has been both witness to and supporter of increased Islamic activity of all kinds. Prior to the twentieth century, from the 1700 s through the 1900s, recitation was transmitted by Muslim traders who settled in coastal areas of the archipelago or by Indonesian pilgrims who, after spending considerable time in Saudi Arabia, primarily in Mecca, brought back the tradition of recitation to their Indonesian disciples. ${ }^{12}$ The systematic reproduction of the Egyptian style of recitation, the style that is considered the model throughout the Islamic world, is a relatively recent development that began in the mid-1960s. When new post-independence alliances were formed with other (Muslim) nations, Egypt began to export its premier reciters to Indonesia, among them 'Abd al-Bâsiț 'Abd al-Ṣamâd, Mahmud Khalîl al-Hușarî, and 'Abd al-Hayy Muhammad al-Zahrah (Moersjied, class lecture 2/28/96; Bahroin 1993:5). Some of the reciters visited Indonesia on more than one occasion and some of them stayed for several years. The style of these Egyptian reciters, and presumably their methods of teaching, were evidently adopted, adapted, and institutionalized in the Jakarta Qur'ân schools PTIQ and IIQ.

Qari'ah Hajjah Maria Ulfah is the administrative director of the Institut Ilmu al-Qur'ân and is in charge of all of the financial affairs. She is Director Hosen's primary assistant in the daily affairs of running the school. She is a recognized reciter throughout Indonesia and a prominent judge at recitation competitions. Of Qari'ah Maria's reputation, scholar of comparative religion Frederick Denny had this to say following an encounter with her at the Biennial National Qur'ân Chanting Tournament held in Kalimantan in 1985:

A premier qari'a (woman reciter) was on hand to demonstrate styles and musical modes for identification. (I had met Maria Ulfa several years before in 
Jakarta and can testify that she is also a crack Arabist, exegete, and legal expert. She is a bona fide celebrity and photographers from TV and the print media are always swarming around her. She won the world chanting championship in Kuala Lampur several years ago, and her creamy contralto is widely recognized and loved. About thirty, Maria Ulfah is dignified and handsome, a kind of Javanese Islamic royalty.) (Denny 1985:35)

It was an honor to have Ibu Maria as another teacher of Qur'anic recitation, not only because of her fabulous reputation and obvious artistic competence, but also because as a women, her voice was more closely matched to mine and in her lessons we focused almost solely on tajwîd and the application of Arab modes to the verses of the Qur'ân. Our lessons occurred either privately or in a small group of girls who were also studying the same passages from the Qur'ân. Toward the end of my stay in Jakarta, I also attended the group lessons in her home that she held for neighborhood women.

I was delighted to study among other women with Qari'ah Maria who was fairly close in age to myself and who also, like myself, was a wife, a mother, and a professional. That women participate actively and in public and on television in the practice of Islam, and particularly in the recitation of the Qur'ân, is one of the strikingly unique features of Southeast Asian Islam. Nelson identifies the tradition in Egypt and the rest of the Arab world as exclusively male:

I refer to a recitation tradition which is exclusively male... . [a] tradition of professional male reciters which is known and imitated all over the Islamic world as characteristically Egyptian. The professional female reciter participates in another tradition, in which musicality is largely unconscious and in which artistry does not figure in the expectations of her female audience (and which men dismiss as "having no art"). Thus the presence of the audience can be attributed more to the particular occasion than to her particular talent as a reciter. There is little interaction between listeners and reciter, and her intent more closely resembles the devotional intent of a more private recitation context. In fact, in keeping with traditional Muslim ideals the professional female reciter is in no sense a public figure. She is neither broadcast over the media nor featured as a personality, nor is she recorded by the public or by commercial companies. Although some women were known for their recitation and were broadcast to the general public in the 1930s and 1940s, they were also known as singers (the most famous being Umm Kaltum). One explanation given me for stopping the practice of broadcasting women reciters is that "a woman's voice makes one think of things other than Allah." However, in Indonesia and Malaysia, where Qur'anic recitation has been greatly influenced by the Egyptian male tradition, women reciters do become public figures. (Nelson 1985:202-3)

In exception to this male domain, however, even in the early twentieth century, the public performance of women's voices reciting the Qur'ân is 
manifest in both the Egyptian and Indonesian contexts as is documented by mass media records of radio broadcasts and wax cylinders (Virginia Danielson, p.c. Oct. 1997; van Zanten 1989: 49). While we have traces of their existence, women's voices reciting the Qur'ân seem to incite controversy. Van Zanten recounts reactions, recorded in 1900 by Snouck Hurgronje, to Indonesian women's voices reciting the Qur'ân both live and as recorded on wax cylinder:

\begin{abstract}
Listening to recordings of Koranic chant was certainly not recommended (mandub), as these were considered only an echo of the live recitation. It was more difficult to decide whether it should be qualified as forbidden (haram) or as objectionable (makrub). If listening to women singing Koranic chant live is objectionable, even if this does not inspire evil thoughts, then listening to their recorded singing is even more objectionable. The main concern was that the voice of another man's wife might arouse erotic feelings. (van Zanten 1989:49)
\end{abstract}

From this we can determine that women recite; however, their recitation, according to van Zanten, would be most likely inappropriate in mixed company, and according to Nelson, would most likely be in the less musically dynamic murattal style. ${ }^{13}$

In contemporary Indonesia, however, things are radically different. While a woman would not lead a religious ritual where men were present, she would certainly recite in the company of men in myriad contexts: in class, through the media of television, radio, and cassettes, at a wedding, in national and international competitions, at governmental festivals and ceremonies (upacara), at conferences, and in small gatherings. ${ }^{14}$ The Indonesian women I met pointed out women's activity in the public sphere as well as their regular participation in mixed-gender events, from sophisticated upper-class evening prayer sessions, to humble kampung (neighborhood) gatherings. Furthermore the vocal and musical artistry of women's recitation is in no way inferior to their male counterparts. Many women whom I met, both students and professionals, take their "singing" very seriously. Many of them have an excellent command of the Egyptian musical style they emulate, and many of them are interested in and/or perform other Islamic musical genres unique to Indonesia.

In searching for some kind of clue to the apparently radical permissibility of Southeast Asian Islam with regard to socially-constructed gender roles, one might look to the deeper and broader cultural framework of Indonesia, particularly Java. Female performers figure prominently and throughout the history of the Javanese courts, whose activities parallel the growth of Islam in Indonesia (Sutton 1989). While santris, devout Muslims in Java, are thought to be somewhat distanced from the world view and praxis of the halus (refined) Javanese (see Geertz 1960), they may well be 
aware of the prestige and "heaviness" of the Central Javanese court traditions whose power and presence is still manifested in artistic performance. The weight of these traditions owes not only to history but to recent "New Order" developments which have effected, in the words of Benedict Anderson, "a Javanization of political culture" (Anderson 1996:293; see also Pemberton 1994). I do not mean to suggest that women reciters are like entertainers. Rather, I recognize the model of the solo female artist as pervasive in Indonesian, particularly Javanese, "high" culture. ${ }^{15}$ The historically prominent female performer type in Indonesia may also pave the way for prominence of all female (and some mixed-gender) groups who perform popular Islamic musical genres including rebana, qasidab, gambus, zikr, lagu shalawat, and Islamic children's songs (see Capwell 1995). ${ }^{16}$

Opportunities for women of all educational and social strata to learn and experience the performance of the Qur'ân are not limited to institutions like the IIQ or the Pondok Pesantren (religious boarding school). Once I had established a pattern of weekly lessons at IIQ I found women's groups all around me (or they found me). For example, one day the maid from the house across the street appeared to convey an invitation from her "woman of the house" to join her in her regular lessons. One of the mosques in my neighborhood held women's gatherings weekly during the year and daily during Ramadan. During these early morning meetings, various women recited from the Qur'ân, and a male 'alim (religious leader) from the mosque gave a sermon. In one kampung (neighborhood), just walking distance from my house, I attended a very simple madrasa (religious school) of a neighborhood woman who tutored women in recitation and lead group meetings where the Qur'ân and other religious material was recited and sung in chorus. While it was exciting to be participant in this active and seemingly liberated Islamic "sisterhood," I occasionally questioned the extent to which official encouragement by the government, work place, family, and educational system for women to learn Qur'anic recitation is not part of a larger project of national conformity, a topic to which I will return below.

\section{Standards of Excellence; Aesthetics of Performance}

Along with the rest of her students, I tape recorded each lesson with Qari'ah Hajjah Maria Ulfah, which I then practiced during the week by playing back the lessons ad infinitum and transcribing Ibu Maria's carefullydemonstrated musical phrases into musical notation. At the following lesson I would perform the recitation from the beginning, she would correct my mistakes, and we would move on to a new passage. By working on an entire ten-minute recitation, the norm for contests (Sûrab [chapter] $A l$ - 
Furqân, Ayât [verses] 64-78), I was able to experience the ways in which the melodic conventions of recitation-modal exposition, modulation, vocal timbre, and ornamentation-are matched to the text of the Qur'ân according to the rules of tajwîd.

Recitation is learned by the "100 times method" (Reck 1996). The teacher sings a phrase and names it using Arabic terms-for example Bayâtî Shûrî or Bayâtî Jawâb. The naming of phrases and sometimes the isolated repetition of musical sequences or ornaments are among the only analytical devices offered in the learning process. The techniques of vocal production are demanding. Women never break into their "head voice" but rather sing in a full if somewhat pinched chest voice through the top of their range. Our recitations covered an ambitus from the $\mathrm{D}$ or $\mathrm{C}$ below middle- $\mathrm{C}$ - often just a rumble - to the $\mathrm{F}$ an octave and a fourth above middle-C; in other words, we sang a range of nearly two and a half octaves without breaking into a head voice. Qari'ah Maria would sometimes demonstrate a high passage in her head voice (suara kecil) but no "real" recitation, male or female, features a "falsetto" delivery. To break into a head voice, even in the highest passages, is to "break the rules."

Like instrumental taqâsim (Arab modal improvisation) a recitation starts with relatively short and unornamented phrases in the lowest part of a singer's range and progresses to longer more fanciful phrases that are filled with ornamentation, sequences, and flourishes in the higher parts of a singer's range and that demand extraordinary breath control. While to Western ears the timbre of recitation may sound nasal throughout, a singer is also required to use nasalization (or extra nasalization) (Arabic: gbunna) as well as unvowelled consonants, for example singing a melismatic phrase on the consonant "nnnnnn," according to the multiple demands of tajwîd. ${ }^{17}$

Seni baca al-Qur'ân requires of a Qari' or Qari'ah the ability to have internalized all of these musical models and to have them available on "instant recall" as they recite any passage of the Qur'ân while simultaneously following the rules of tajwîd. Memorization of parts of the text of the Qur'ân can also be a goal for Qari' and Qari'ah. While recordings of men's and women's recitations can of course be distinguished, there is no effort on the part of women to sound like a woman, or to sound feminine, or to sound in any way different from a man. When they recite, Qari' and Qari'ah are channeling the archetypal recitation of the Qur'ân as it has been practiced, according to Muslim belief, for centuries.

A profusion of documents exists in Indonesia on the history, use, understanding, memorization, and recitation of the Qur'ân (see Federspiel 1994); however, the musical aspects of recitation must be learned aurally and orally through practice. Documents I have read describing musical aspects of the Qur'ân provide only the texts of tawâshîh and the corre- 
sponding musical mode to which they are to be sung (see Shalihah 1983). Sometimes, in discussing a mode (for example, maqam Șabâ) the name of a melodic variation or cadence (qaflab) in that mode is indicated (for example, maqam Sabâ, qaflah Bastanjar); however, it is assumed that the melodies of these modes and cadences will be learned through audition and practice. ${ }^{18}$

Despite the fact that there is little written (or spoken) discourse regarding the musical aspects of recitation, many Jakarta reciters, compared to Egyptian models, are impressive! As mentioned earlier, I was continuously astonished at the conformity between the musical models, melodies, ornaments, characteristic accidentals, and vocal techniques and timbres that my Jakarta teachers demonstrated to me and those I learned through my studies and performance of Arab music. Even my colleagues who are scholars of Arab music have been amazed at the precision with which Jakarta reciters duplicate, yet with creative originality, the Egyptian style of recitation (p.c. G. Sawa 3/23/97 and S. Shawan Castello-Branco 6/30/97).

Like musicians, reciters enjoy celebrity status, and through their teaching and judging promote high standards of musicianship, virtuosity, and technical ability among practitioners. Moreover, the Qur'ân, because it is meant to be recited aloud rather than read silently, is enjoyed as a kind of musical oratory. While the meaning of the Qur'ân is central to Islam, the divine origin and power of the sound of the Qur'ân is something experienced on a purely aesthetic level, particularly in a society where few understand the Arabic language. On two occasions when professional reciters visited the IIQ (from Iran and Malaysia), special gatherings of the IIQ's students (all armed with tape recorders) and faculty were assembled in the director's air-conditioned office simply to enjoy each other's recitation for the duration of the afternoon. In this context, which they called nadwab (Arabic: salon/soireé), there was no discussion of tafsîr (Qur'anic commentary) or other religious topics.

When an Iranian reciter visited, escorted by two compatriots from the Iranian embassy, an ensemble of five of Qari'ah Maria's finest students recited a complex, completely memorized selection from the Qur'ân, which they had obviously been perfecting for some time. ${ }^{19}$ Others recited solo, Qari'ah Maria recited, and the Iranian Imâm recited, which was a great pleasure for all gathered. ${ }^{20}$ In June when I was a guest at the Pondok Pesantren of Moersjied's family in South Sumatra, recitation was a part of every presentation. I myself was coerced into performing for 300 or so students and faculty during a sort of open-air talent show on the night before the graduation ceremony. The appreciative and affirming shouts of "Allah!" (God) that punctuated each phrase of my nervous recitation, contributed to one of the most powerful performance experiences of my life. 
Figure 2. Students of Qari'ah Maria Ulfah reciting together for Iranian guests.

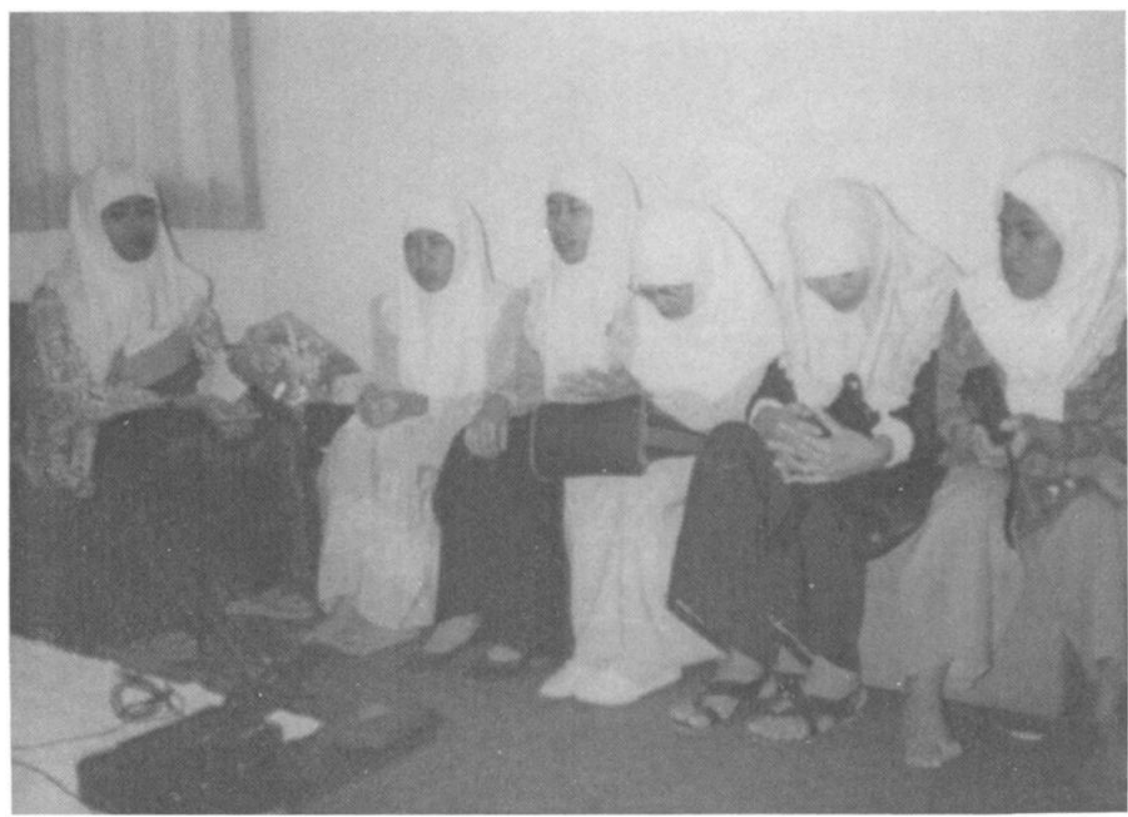

\section{Jakarta Reciters as Ritual Specialists}

In addition to their roles as teachers, reciters, particularly male reciters, fulfill an important role as ritual specialists. Their services are in high demand at numerous occasions from the opening of a new office building to funerals and particularly during the month of Ramadan, the busiest season of the year for professional reciters. Every evening during the month of Ramadan a special prayer session follows the breaking of fast after the maghrib or sundown prayer. Shalat al-Taraweb (Șalât al-Tarâwiḩ) are not obligatory but they are communal and religious rituals, and people seem to attend them as much out of social interest as religious obligation. At a Shalat al-Taraweh the function of the Qari' is indispensable for it is he, as the Imâm Shalat, who leads the gathering in prayers, the structure and order of which is of the utmost importance. Before outlining the ritual structure of the prayer, I will describe the setting or "macro structure" of the three Shalat al-Taraweh I attended during Ramadan, 1996.

The Kelompok Yaysasan Pengajian Proklamasi 36 (Group of the Cultural Center for Recitation Proclamation 36) hosts a Shalat al-Taraweh every evening during the month of Ramadan. The event I attended constitut- 
ed a special occasion as a group of perhaps 300 well-dressed men and women from the Yayasan Pengajian Proklamasi 36 gathered in the upstairs lobby of the five-star Sahid Jaya Hotel in Jakarta's central business district. The evening, from about 5:30 to 10:30, unfolded as follows. The precise moment for the breaking of the daily fast (buka puasa) was indicated by the televised call to prayer from the national mosque, Masjid Istiqlâl. Following tea and light snacks, congregants performed ritual washing (wudbu) in the men's and ladies' rooms and gathered together in a large ballroom for prayers. ${ }^{21}$

Following prayer, a buffet dinner was served in an adjacent room where seating at round tables was voluntary and mixed by gender and age. Then the Shalat al-Taraweh proper occurred in the main ballroom where rows and rows of prayer rugs supplied by the Sahid Jaya hotel were already set up. In this context Qari' Moersjied served as Imâm, the leader of the congregation, assisted by his brother Muchlis, who comes from the family's Pondok Pesantren in Sumatra to Jakarta every Ramadan to assist Moersjied with his busy schedule of engagements. ${ }^{22}$ The Shalat al-Taraweh proper, which lasted for about an hour, was preceded by announcements, and followed by a light meal served on a tray to all seated (on the floor). The evening was capped-off by a forty-five minute lecture by a high school principle who spoke about the compatibility of Islam with educational reform. His highly entertaining address was complimented by attractive graphics projected overhead. As we descended the escalators from the first floor to the main lobby of the elegant Sahid Jaya Hotel, a professional photographer already had candid photographs of attendees, with captions identifying the event, mounted on bulletin boards for sale.

The second Shalat al-Taraweh I attended was hosted by a private family and occurred at the spacious home of Pak Iwan Yusef. Evidently this family holds a Shalat al-Taraweh every year; among the guests were elite business people, embassy personnel, academics, and family members. Tables and booths featuring catered food from several areas of Asia were set up around the back patio and swimming pool and there was plenty of time to mingle and socialize both before and after the ritual prayers. On this occasion I was with Qari'ah Maria, who of course as a woman, had no ritual duties, but who participated in the collective ritual in one of the rooms of the house, which during the prayers proper was designated for women. The Imâm who had been hired for the event led the prayers and recited selected verses from the Qur'ân through a small sound system in the largest room where the men were situated.

Alongside the evening prayers held in elegant hotels and private homes is the most common context for Shalat al-Taraweh: the mosque. Every mosque holds nightly prayers and anyone can attend. The third Shalat al- 
Taraweh I attended was at the invitation again of Qari' Moersjied who was to be the Imâm at the Masjid Al-Taqwa, a fine, newly constructed mosque near downtown Jakarta. When I arrived and found my place in the balcony, there was only one other woman there. Before the beginning of the prayers, however, the balcony was packed with women and the main floor with men. Shalat al-Taraweh consists of a series of rak'ât or prostrations, each of which itself consists of several movements-rukûn: standing, kneeling, bowing to the ground-that correspond to the words and recitation of the Imâm. Each rak'a lasts about five minutes and there can be anywhere from eleven to twenty-three rak'ât in an evening's prayer session, which lasts in its entirety about an hour and a half. Moersjied's assistant and brother Muchlis punctuated many of the rak'ât by bursting into a performance of devotional, religious text (not from the Qur'ân) loudly, at the top of his vocal range, and with a highly decorated melody. During these performative links, participants responded audibly and Moersjied often joined in with responsorial sung lines.

Qari' Moersjied later helped me to analyze the complete structure of the evening's ritual, with the help of my video recording. With his recitation, his spontaneous choice of memorized verses from the Qur'ân, and his physical actions, the Imâm, like any ritual specialist, helps the congregation to experience religion. The Shalat al-Taraweh, like any religious ritual is performance, and the Imâm, through their knowledge of liturgy (music, text, and movement) enables the activation of religious community through ritual performance. For a Qari', Shalat al-Taraweh are not only demanding intellectually and emotionally, they are also demanding vocally because it is in this context that an Imâm must recall, with spontaneity and spirituality, all of the aspects of vocal artistry and tajwîd mastered during training.

\section{Qur'ân Competitions and the Festivalization of Religion}

Except in the context of a private, all women's gathering, leading prayers is the sole territory of the Qari'; however, both men and women participate in recitation competitions, another context in Indonesia where the oral transmission of the Qur'ân is promoted and publicized. Judging competitions is a cornerstone of reciters' professional activities as well as a source of income. Jakarta Qari' and Qari'ah often travel to other cities and towns to judge competitions sponsored by groups ranging from government organizations to private companies. I cite three competitions I experienced during the course of ethnographic work in 1995-1996.

The Sayembara Adzân, Festival Istiqlâl, Jakarta, November 1995, was a call-to-prayer contest that featured contestants (all male) from throughout Indonesia who gave their renditions of calling the faithful to prayer. The 
contest went on for several days from morning to afternoon, one adzân after another. A group of eight judges evaluated the contestants according to a point system following these criteria:

- Suara: Voice

- Irama: Timing, rhythm, tempo

- Pengaturan Nafas: Regulation and control of breath

- Tajwid: The rules dealing with the sectioning and treatment of the text

- Fasobah: Eloquence; fluency

- Adab: Comportment; good manners

In December, of 1995, Qari' Moersjied invited me to the Musabaqah Tilawatil Qur'ân (Musâbaqat Tilâwat-al Qur'ân) or MTQ an all day final competition for the recitation of the Qur'ân hosted by Minister Mordiano the Sekretariat Negara (secretary of the government at that time). This day was the test for thirty-seven finalists-from within the ranks of all of the employees of the Ministry of the Secretary and their families-males and females, divided into three groups, children, adolescents, and adults, who had already won a preliminary competition held earlier in October. At this tournament, two contestants recited simultaneously from two stages; two tables of judges on either side of the stage judged them according to the following criteria:

- Suara: Voice quality

- Jumlab lagu: The total number of melodies or maqâmât sung (and heard)

- Lagu pertama dan tenutup: The choice of opening and closing maqâm

- Peralihan, keutuban dan tempo lagu: Transitions and the totality of the tempo of the tune

- Irama, gaya, dan variasi: Styles and variations in rhythm and timing

- Pengaturan nafas: Breath control and regulation

- Adab: Comportment; good manners

It is interesting to note that various judges are responsible for evaluating different aspects of the recitation. One group or individual may evaluate matters of text, while another matters of comportment. Judges assign points for each category, and the points are tallied to determine a winner. The judges are concerned with very specific technical detail; consider, for example, the category of jumlah lagu, the total number of melodies (or modulations) heard. Sitting at a table and counting modulations would, in a Western context, be analogous either to sitting at a concert of classical music and tracking the modulations to various keys in the development 
section of a symphony movement, or to noting specific voicings and chord progressions in a jazz performance. While not impossible, these kinds of musical talents require very sophisticated musical perception.

On February 5th, 1996 I was in the studio audience as a guest of judge Qari'ah Maria Ulfah for the Final Pekan Tilawatil Qur'ân, the national final competition for the recitation of the Qur'ân, where the contestants had been whittled down to five men and five women. This event was broadcast live on TVRI and RRI (Televisi dan Radio Republik Indonesia). Male and female contestants, who had been assigned a passage to prepare earlier in the day, were presented in alternation. A female host presented the male contestants, and a male host presented the female contestants. The tenminute recitations, the timing of which is indicated by a series of green, yellow, and red lights, were aired in their entirety. The audience of invited guests, relatives, and students (with tape recorders) were arranged in voluntary mixed gender seating, with dignitaries in the front row.

Following the presentations by all contestants, the judges retreated to deliberate. The Minister of Religious Affairs, Dr. H. Tarmizi Taher, addressed the audience briefly and stressed that during the month of Ramadan we should all work on reading the Qur'ân and understanding its meaning. Following the Minister's speech, a band featuring electric guitar, keyboards,

Figure 3. A band plays Islamic pop music while the judges deliberate during a televised recitation context.

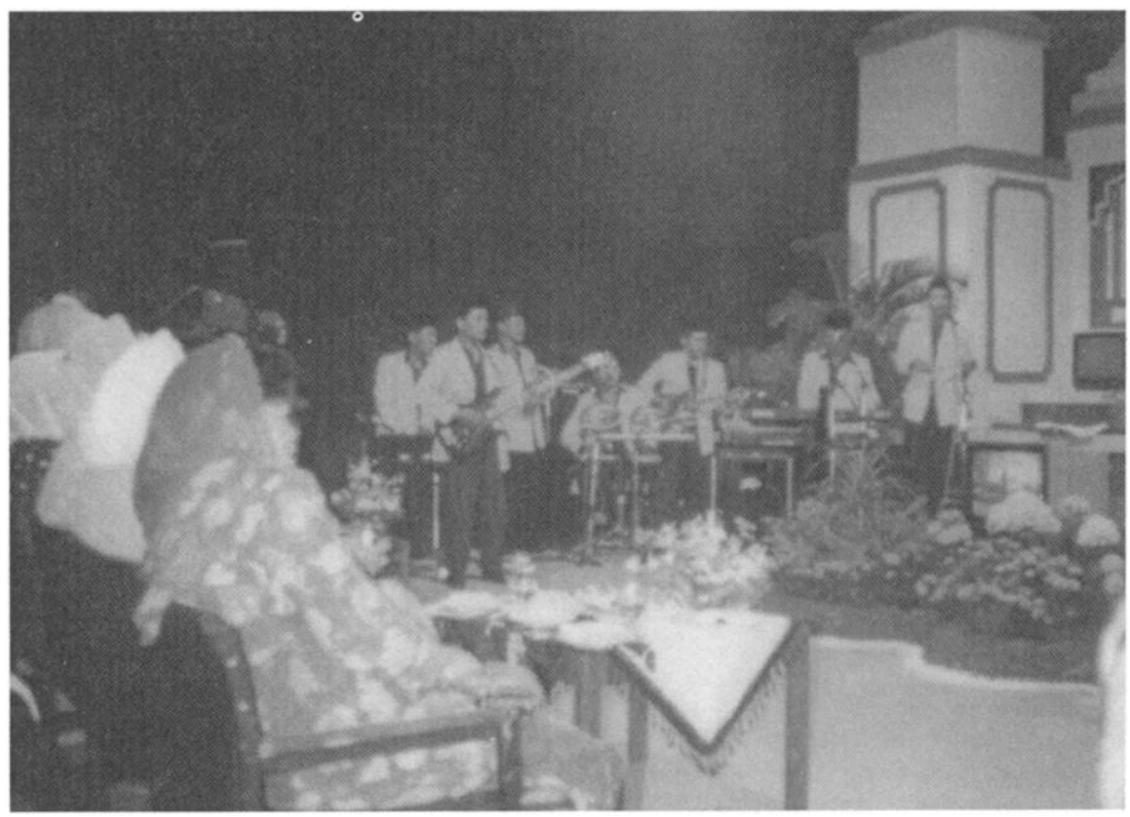


drums, and flute accompanied women singers who sang religious pop music, including one or two popular Egyptian songs. The musicians wore snazzy matching outfits and the singers, sequined busana Muslim. Finally, the nine judges made their entrance and stood in a row on stage. Kiyai Haji Sayyid Mohammad Assiry, perhaps the most respected of teachers and judges of Qur'anic recitation, as well as an Imâm Besar (great leader of prayers) at the presidential palace (Mesjid Bayt ur-Rahim, Istana), announced the results.

Competitive events do not seem particularly religious and for the Qari' and Qari'ah who judge them they are work. Yet competitive events such as these contribute to the consistent, correct, and respectful recitation of the Qur'ân. Those who do this well are judged formally, and rewarded with public pomp and circumstance. In the case of the "National Final Competition in the Recitation of the Qur'ân," the man and women who placed first received a certificate, a trophy, a 20-inch color television set and a monetary prize. The pair who placed second, the same, but with a 17 -inch color T.V., those who were third, the same with a 14-inch T.V., and the fourth place contestants, the same with a radio.

\section{The National Project of Recitation}

For each competition I experienced, the Indonesian government was the major if not the exclusive patron of the event. The reasons for the government's zeal for Islamic activity are many. First Indonesia's New Order government ushered in a set of five guiding principles for the country and its future direction. Called Panca Sila (five principles), these guidelines include: "belief in one, supreme God; Justice and civility among peoples; the unity of Indonesia; democracy through deliberation and consensus among representatives; and social justice for all" (Schwarz 1994:339). The notion that spiritual development should accompany physical and particularly economic development (Federspiel 1994:23) has been fodder for numerous government programs, policies, speeches, and celebrations. As Federspiel has observed: "Street signs and television announcements are likely to make reference to such matters (religious duties and nation building) using Nationalist concepts: 'Qur'ân recitation is a way of building the spiritual basis of religion and nation'" (ibid.:27). One of the most important documents reviewed by Federspiel (and mentioned above), "The Development of the Art of Reciting the Qur'ân and the Seven Forms in Indonesia," provides government-sanctioned guidelines for recitation competitions where four levels of contestants are evaluated: children, youth, adults, and handicapped (ibid.:93). Denny, from his experience researching the phenomenon in Indonesia observes: "MTQ is widely hailed in Indonesia as a disiplin nasional" (1988:295). Denny's colorful descrip- 
tion of the Biennial National MTQ in Kalimantan 1985 and my own experience suggest a kind of politically organized festivalization of religion:

Trucks, jeeps and floats sponsored by religious, educational, and civic organizations as well a businesses passed by, maybe a hundred in all. The Qur'ân was the most common theme, and so there were displays of large open scripture representations, calligraphy, mosques on wheels, complete with papier-maché minarets, and trucks carrying recitation teams from all the twenty-six provinces of Indonesia, all in native costume. (Denny 1985:34)

In some ways the great energy and fanfare that goes into these governmentsponsored productions of religious practice may be compared to public traditional ritual, or upacara tradisional, which Pemberton interprets as a creation of Suharto's New Order Indonesia (1994:9). Pemberton observes that former President and Mrs. Suharto's appropriation of culture (kebudayaan) as a deliberate strategy for control of vast numbers of economically disenfranchised and ethnically diverse Indonesians has been made manifest in huge cultural projects. Such projects include Taman Mini Indonesia Indah (an enormous Indonesian theme park, inspired by Disney World), the re-choreographing of "authentic" palace traditions from Central Java, and "cultural representation" around national elections called "Festivals of Democracy." Pemberton quotes President Suharto's address from the souvenir booklet of the opening of Taman Mini:

Economic development alone is not enough. Life will not have a beautiful and deep meaning with material sufficiency only, however abundant that sufficiency might become. On the contrary, pursuit of material things only will make life cruel and painful. . . . One's life therefore, will be calm and complete only when it is accompanied by spiritual welfare. . . (ibid.:174)

Surely, huge competitions where people from all walks of life witness, listen to, watch, try to perfect, judge, and reward Qur'anic recitation from the holy book and highest authority of Islam qualifies as leading to the spiritual welfare of the nation. In addition to promoting spiritual welfare and growth, the widespread publicization of recitation in the Arabic language serves as yet another way to unify the vast nation of Indonesia, propelling diverse peoples even more strongly into an "imagined community" (Anderson 1983).

I was able to witness the marriage of religion and government most vividly during my visit to Pondok Pesantren Al-Itifâqiah ${ }^{23}$ located in Indralaya OKI, in South Sumatra. On the day following the graduation ceremonies, which were peppered with mutually-congratulatory speeches by Pesantren directors and local government and military officials, we all proceeded to the local soccer field where students from fourteen Pondok Pesantren in the local area celebrated the pilot program of a new govern- 
ment initiative: ABRI Masuk Pondok Pesantren (The Army Enters the Pondok Pesantren). The program was evidently modeled on another recently successful government program, ABRI Masuk Desa (The Army Enters the Village) in which local military provided helpful services to rural villages. For this celebration, the students of each of fourteen Pesantren presented a march, a pageant, and recitation from the Qur'ân - the sum was a sort of Indonesian version of what one would see at a high school football game at half time. Moersjied's brother Muchlis had prepared an extraordinarily extravagant pageant of about twenty minutes involving all of the 150 or so female students, from their school, Al-Itifâqiah. As the girls, in matching costume, performed in formation on the field, the music of Egyptian singer Umm Kulthum blared over the loudspeaker and Muchlis, holding a microphone, delivered a narrative explaining the choreography. First, he narrated, came the girls of the Pondok Pesantren who paraded around in circular formation in stylized gestures of prayer and worship. Next, the commentary continued, came the army, still portrayed by girls but identified by their camouflage colored berets. In the final stage of the pageant students from the Pondok Pesantren and army personnel joined together and worked on projects to "develop the nation."

Coming away from the delightful yet overwhelming sojourn at Pondok Pesantren Al-Itifâqiyah left me with the feeling that Islam is not only a spiritual endeavor but also a civic obligation.

Figure 4. Students from Pondok Pesantren al-Itifâqqiah perform a pageant.

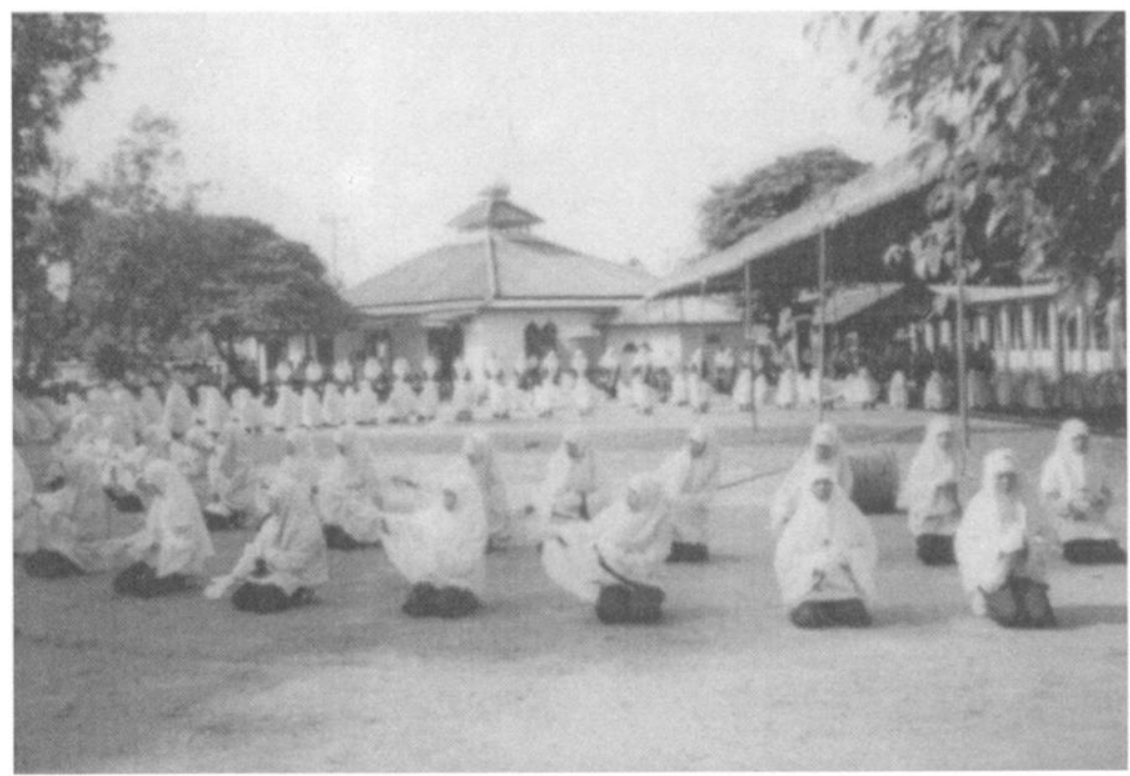




\section{Reflexive Reflections on Dakwab}

Unlike many music-making opportunities in ethnomusicological fieldwork where women are an accepted exception, in Jakarta, there are numerous contexts in which women learn and practice Qur'anic recitation. In compliment to my position as an American and a non-Muslim, my status as a wife and a mother enhanced my normalcy. My three-year-old son was a familiar sight to all who came into contact with me. My status as a teacher and a musician - an "intelektual" - also enhanced my mobility within the culture of recitation in Jakarta. So unlike going to nightclubs or tagging along with male musicians to wedding gigs-activities that have constituted my fieldwork among Arab Americans prior to my experience in Indonesia-this was a welcome and appropriate scene for me, in spite of my obvious position in terms of my ethnic, national, cultural, and religious background as an outsider.

My Indonesian colleagues immediately saw contributions I might make to their own curriculum, for example teaching Arab music. I frequently brought my 'ûd along to IIQ and we discussed the musical elements of recitation and Arab music with two languages: music and words. They were interested in the way I talked sabout music and played it, and how I could read and write musical staff notation. Toward the end of my stay they saw the potential of our continued collaboration.

I suspect however, that while my teachers understood and tolerated my position as a non-Muslim college professor, many, particularly the students, saw me as a potential believer. The term dakwah (da'wab) connotes a number of activities that can include: bringing others to the faith of Islam; strengthening the faith through more participation in religious activities; or rediscovering the faith, almost in the way of being "born again." In fact one can "major" in dakwah (missionary work/proselytizing) in the Islamic education system of Indonesia. The queries of my young classmates revealed the most about my position in their culture and I explained daily my position with regard to faith. At every visit to IIQ, students and I would gather in the lobby, or visit before class: "Did I like wearing Muslim dress?" "Did I wear it all time?" "Did my husband approve?" "Did he see me in Muslim dress?" "Did he tambab cinta literally 'add love' when he saw me in busana Muslim?" In one conversation I asked my classmates why I should convert to Islam. One young woman replied in essence: "You are an intellectual (seorang intelektual) and as such you understand what is in the Qur'ân and if you were to convert it would be a wonderful model for Indonesians and you could explain to us the meaning of the Qur'ân and of Islam." 24

The art of reciting the Qur'ân, seni baca al-Qur'ân, is an artistic and religious phenomenon central to national and cultural identity in Indone- 
sia. Islamic values and practices that are on the rise in contemporary Indonesia are intensified and empowered by recitation and related musical practices. Islamic educational institutions - from the religious boarding school, Pondok Pesantren, to the many Islamic Universities in Indonesia-produce hundreds of graduates, who, if not reciters themselves, are used to having excellent reciters in their midst. The broadcast of Qurânic recitation through the sound systems of neighborhood mosques and on the majority of Indonesian television and radio stations ensures that recitation will reach the ears of all citizens.

The public role of Indonesian women in this complex is intriguing and impressive and I was pleased to be welcome among this sisterhood. Certainly the prominence of women makes Indonesia seem more "in step" with Islam as a modernist project. Yet, the official encouragement by the government, work place, family, and educational institution to encourage women to learn Qur'anic recitation may also work in consort with the government's goal of spiritual development, the Islamic project of dakwah, and also the national institution of "Ibuism" whereby "women's powers [are] increasingly harnessed to the interests of the new state" (Sears 1996:34). Madelon Djajadiningrat-Nieuwenhuis discusses this phenomenon at length as a strategy of post-revolutionary, New Order Indonesia:

But also the new Indonesian society called upon the "kaum Ibu" (community of mothers) to put their shoulders to the task of building a new national state; and more than the men, they were expected to do this disinterestedly. The honour they could gain was that of being a good Ibu. Power and prestige remained the privilege of men. (1992:43)

Indonesia, like Islam, is "consensus minded" culture, where "togetherness is a way of life" (Denny 1985:37). Whether it be the Dbarma Wanita, the association of civil servant's wives whose banners and publicity decorate the sky scrapers of downtown Jakarta, or the experience of Qur'anic recitation that is sought out by women of all socio-economic classes in their homes, their neighborhoods, at fancy parties and hotels, or as their life's educational pursuit, group projects of conformity that de-emphasize individualism and underscore the publicized principles of the state are congratulated in contemporary Indonesia, whatever the intention of the individual.

When not mapping the webs of politics, power, and gender onto the Islamic arts in Indonesia one can always return to the sound. Reciting the Qur'ân is an authentic act primarily because people think it so. Qari' Moersjied emphasized that those who can recite, teach, and understand the meaning of the Qur'ân are few. On the other hand those who do not understand but recite well are numerous. When you recite the Qur'ân you are channeling an archetype. Physicality, showmanship, and even gender are 
de-emphasized in relation to the power of the sound. While the musical level of recitation in Indonesia has been flexible for the past five centuries, Indonesian Islam is, for the time being, propelling Egyptian performance practice into the twenty-first century. The mechanisms that have been set in place by male Qari' and female Qari'ah, educational institutions, the mass media, and the government festival have effected a rich musical/religious complex that may serve as a model for any culture seeking to invigorate religious and traditional performance.

\section{Notes}

1. This article is based on presentations I gave at the Conference of the Society for Ethnomusicology (Pittsburgh, PA, October 1997) and the International Council for Traditional Music (Nitra, Slovakia, June 1997). The work was revised upon my return to Indonesia in February of 1999 where I continued this project supported by a Fulbright Senior Scholar Fellowship under the official sponsorship of the National Islamic University, IAIN (Institut Agama Islam Negeri), Jakarta. Among the many people who have given me valuable feedback, I am particularly grateful to ethnomusicologists Ali Jihad Racy, David Harnish, and Virginia Danielson as well as to my Indonesian colleague Dadi Darmadi of the IAIN. I also thank my colleague Sophia Serghi for transferring my handmade transcription into the beautiful computer-generated musical example that appears in the article.

2. A note on foreign terminology and transliteration: the title $I b u$ connotes maturity, marriage, and motherhood and is used in the Indonesian language (Bahasa Indonesia) for adult women. The term Bapak or Pak is used for adult men. Although I called professional reciters "Pak" and "Ibu," I use their professional titles Qari' and Qari'ab throughout the article. For Indonesian terms that are derived from the Arabic language, I generally use Indonesian spellings and provide, in parentheses, the transliteration of the Arabic term following the IJMES system (International Journal of Middle Eastern Studies) when there are obvious discrepancies in the transliteration systems.

3. The 'ûd is pear-shaped fretless lute found throughout the Arab world and in parts of Central Asia and the circum-Mediterranean region. The lack of frets on the neck of the instrument enables a player to produce the non-tempered intervals, sometimes referred to as "neutral" or "quarter" tones, characteristic of Arab modes or maqâmât. I have been playing the instrument for more than ten years. In Indonesia the 'ûd is commonly referred to as gambus (see Capwell 1995).

4. As I look back to my field notes I read with amusement:

I played a dulâb in Bayâtî and then a taqâsîm-Pak Moersjied recognized it as Bayâtîhe ooed and ahhed and began to sing-I modulated to Rast on G and then Hijâz which he also recognized-he seemed truly thrilled-as was I. I played a bit more-he asked for Sikab-but I wasn't about to modulate to Sikah when I had just started in Bayâtî. But I played a nice bit in Șabâ and he started vocalizing along. Well that was about it but then one girl asked please sing. So . . what should I sing, what should I sing-Of course! - The old standby of Arab traditional music: "Lamma Badâ Yatathanna." Well, Pak Moersjied seemed to recognize the tune and generally my singing just put them all over the edge. (November 17, 1996).

5. I acknowledge at the outset Kristina Nelson's fine ethnography The Art of Reciting the Qur'ân (1985), a book that is based on her dissertation fieldwork among professional reciters in Cairo, Egypt. In Indonesia, recitation is commonly referred to as seni baca al-Qur'ân or seni baca Qur'ân, literally the "art of reading (reciting) the Qur'ân. 


\section{Ethnomusicology, Winter 2001}

6. The audibility of call to prayer and recitation seems to vary in countries where Islam is prevalent. When I visited Syria in 1994 I frequently froze in my tracks, captured by the musical beauty of various Muezzin as they projected their Adzân (call to prayer) through loudspeakers from the mosques. During a trip to Morocco in 1997, I was struck by the rather modest space that call to prayer and recitation occupied in the public soundscape. These "noisy" aspects of Muslim practice have been of some concern in Singapore (see Lee 1999) where the volume of call to prayer has been legislated and to some degree silenced. In Jakarta, Indonesia however, where street life tends to be dynamic and boisterous, Qur'anic recitation, speeches, and call to prayer are broadcast from loudspeakers from mosques large and small throughout the city. From our house in South Jakarta I could hear the activities of five nearby mosques from the back patio. (See also Sutton 1996 for an insightful interpretation of the ways in which continuous, lively, overlapping sounds are a natural and desirable part of the Javanese public and private soundscape).

7. Michael Sells, whose manuscript Approaching the Qur'ân attempts to translate the power of the recited Qur'ân for non-Muslims or those unfamiliar with its performance, writes that an explanation for its powerful effect on listeners is found in the Qur'ân itself. If Muhammad was a prophet, as he claimed he was when he began receiving the divine revelations, "where," his contemporaries asked, "was proof of a miracle." "The answer, as recited by Muhammad in the form of another Qur'anic revelation, was that the Qur'ân itself was the miracle. If anyone could produce anything like it, then the Qur'ân was a human creation and Muhammad a false prophet. If, however, no one else could produce anything like it, then the Qur'ân was clearly beyond the capacity of a human being and Muhammad would not be its author, but simply its messenger. . . . within Islam generally, the Qur'ân has been recognized as having proved itself inimitable" (Sells 1999:2).

8. The Indonesian term lagu Arab is commonly used to mean Arab tune, melody, mode, or song. I have heard the Arab words mode (maqâm), melody (labn), and song (nagham) regularly translated into Indonesian as "lagu Arab." However, the Indonesian publication "Nagham (Seni Baca Al Qur'ân)" by Drs. Bahroin (1993), renders the similar statement in Arabic: "Iqra' al-Qur'ân bi-l-lawn 'Arab" into the Indonesian translation: "Bacalab al-Qur'ân itu dengan dialek 'Arab" or with Arab dialect, a statement that refers to the seven qira'at or phonetic systems of recitation associated with prominent reciters who followed Muhammad in the eighth century (Nelson 1985:3). Maria Ulfah has concurred in recent conversations with me that sometimes in Indonesian publications the distinctions between the seven maqâmât used for recitation and the seven qira'at or styles of narration are unclear. Of course in practice these aspects of recitation are perfectly distinct.

9. I am indebted to Kyra D. Gaunt who introduced the term "oral kinetic etudes" in reference to sound and movement passed on through generations of African-American children with little adult intervention (1997).

10. The most well-documented music of Indonesia is gamelan music, of which there are many variations. Due to the ethnic and regional diversity of the Indonesian Archipelago there are hundreds of regional and ethnic genres of music as well. That the comparison of recitation with music is an "issue of grandeur" as I state, may well be an assumption perpetuated by Western scholarship on the Middle East which has found fascination with the lines of legitimacy that are drawn around social and artistic practice.

11. Indonesian independence was declared in 1945. Sukarno, the first leader of independent Indonesia, was overthrown in a military coup in 1965 at which point president Suharto took over (see also Schwarz 1994). Suharto's rule of more than three decades, referred to as the "New Order," ended when he was forced out of office in May of 1998. Prior to the free elections involving a myriad of new political parties in 1999, Suharto's colleague, Habibie, became president. His government and "Kabinet Reformasi" was considered "transitional." Abdurrahman Wahid and Megawati Sukarnoputri were elected president and vice-president in parliamentary elections in November of 1999. Reformation (reformasi) at this writing is ongoing. 
12. The melodies and styles and even the genres of religious song learned in Mecca may still be marginally preserved in certain enclaves of Indonesia. When I visited the Pondok Pesantren of Moersjied's family in South Sumatra (June 1996) I was treated to renditions of Barzanji (special songs for the prophet) performed in a musical style that was brought from Mecca. Moersjied's grandfather, who spent twenty years studying in Mecca, married his grandmother there, an Indonesian, also living in Mecca. As a result Moersjied's father was born and grew up there, and the marginal preservation of a practice originating in Saudi Arabia, now easily overshadowed by Egyptian practice, prevailed in the family's pesantren Al-Itifâqiab in South Sumatra.

13. Virginia Danielson writes that women singers in Cairo in the 1920 s performed in many of the same contexts as their male counterparts: "They recited the Qur'ân, usually for other women" (1991:293).

14. While women don't lead religious rituals, they certainly contribute to them with their performances. For example, on the occasion of the death of Ibu Tien, President Suharto's wife in 1996, a busload of female students and their professors from the IIQ were dispatched to the presidential palace. Once there, these young female college students recited the entire 114 chapters of the Qur'ân, in consort, in about an hour's time, once student per juz' (part).

15. To assume that women performing in "high" culture, for example pesinden (female singers) in a court gamelan or in a prestigious wayang kulit (shadow puppet) troupe also have "high" status would of course be naive. See Susan Pratt Walton's dissertation (1996) for and analysis of the changing perceptions of female performers in Java (see also van Zanten 1989:45).

16. I asked a number of Indonesians if women recited in public in the Arab world. They thought not. "Why?" I asked. "Because the voice of a women is too provocative for a man," they offered. "Why, then, can women recite in public in Indonesia?" I persisted. The general response: "Because we don't have that problem here." At their family's Pondok Pesantren in South Sumatra, Moersjied's brother, Muchlis revealed that he felt women were, in fact, much better than men at artistic endeavors, especially dance and music. Boys preferred comedy and sport, according to Muchlis. Over the course of three days of graduation festivities I witnessed girls performing qasidab (a kind of Arab religious song) with rebana (frame drum) and rehearse for a huge pageant set to music and choreographed by Muchlis. The two star reciters at the Pesantren were girls.

17. Danielson translates ghunna as: “'sweet nasality' a desirable tone color in song” (1997:203).

18. Khadijatus Shalihah's 1983 publication Perkembangan Seni Baca Al-Qur'ân dan Qira'at Tujub di Indonesia (The Development of the Art of Reciting the Qur'ân and the Seven Forms [of recitation] in Indonesia) is an excellent source on the topic. She includes all of the texts of the commonly taught tawâshîh and the modes that are to be used to sing each line of poetry. Her description of Arab modes, which combines Indonesian with Italian language musical terms such as adagio, lento, and grave, highlights the limitations of language (and, perhaps the adaptation of terminology from other languages) for describing music. In his comprehensive review of Indonesian literature regarding the Qur'ân, Federspiel also refers to Shalihah's study but his account of her description of melodic modes is confusing:

"Shalihah's study also outlines some of the terms used to differentiate among those styles, noting that the bayati (adagio), shaba (allegro), bijaz (grave), nabawan (allegro), sika (grave), raost (allegro), are the most common for Indonesia. These forms are taken overwhelmingly from Egypt and, probably, from the tradition of Ummi Kalthum, an early developer of the practice of adapting the verses of the Qur'ân to music." (Federspeil 1994:94)

Although many Indonesians may point to Umm Kulthûm as the person who built the bridge between recitation and music, the correspondence between Qur'anic recitation and song predates her performances, as most Indonesians will admit. (See, for example, Danielson 1997. 
Chapter 2, for her discussion of Masbayikh-singers of religious music.) Since my return to Indonesia (1999) I have been able to discuss many of these issues with Khadijatus Shaliha herself.

19. The recitation of the Qur'ân is normally a solo endeavor except in cases where students might recite in imitation of a teacher. Ibu Maria believes that there is nothing in the Qur'ân that prohibits group recital and gave a paper at a colloquium of IIQ faculty, supporting her argument with statements from the Qur'ân and the Hadith (Ulfah n.d.).

20. Had I been able to communicate better with the Iranian guest it would have been interesting to hear his reaction to hearing so many women recite-and in mixed company. He was smiling continuously so he seemed to be enjoying himself.

21. Prayers are segregated. In this case women occupied the back half of the hall room whereas men were in the front closest to the Imâm (leader of prayers) who in this case was my teacher Qari' Moersjied. For the duration of the prayers only, women don a white prayer gown and head covering under which they can wear whatever they want. At this event the women wore very fashionable batik clothing and often quite sheer matching head scarves.

22. I found it fascinating that Qari' Moersjied is completely in charge of his own work as opposed to being "booked" by an institution such as the Ministry of Religion or even the IIQ. Professional reciters develop their own clientele and are remunerated by these patrons in the form of honoraria.

23. The term Pondok Pesantren means Islamic boarding school. The word Pondok comes from the Arabic funduq (hotel). The term pesantren comes from the Indonesian santri, the term for a devout Muslim (see also Denny 1989 and Geertz 1960).

24. The comments of my young classmate resonate with the observations on Islamic Revivalism recorded in Adam Schwarz's A Nation in Waiting. I quote both him and Bill Liddle at length here (Schwarz 1994:173-4):

The former concerns the desire of many Indonesians, particularly the young, to find in their religion a stable bedrock of belief in a rapidly changing, modernizing and often confusing world. They appear to be interested neither in the traditional ritualistic dogma of conservative ulama or the messianic fervor of some modernists who want Indonesia to become a theocracy. Instead, they are looking for ways to make Islam more relevant to life in the modern world. Bill Liddle explains:

[Younger Muslims] are looking for a new understanding of their religion that gives them a more realistic set of guidelines, really a code of ethics, for private and family life and for dealing with the outside world. they want to know what are the rights and responsibilities of husbands and wives, how to raise their sons and daughters to be good Muslims, how to relate to a modern banking system, whether and how to revitalize the concept of zakât (religious tax), and even how to deal with such exotica as test-tube babies, organ transplants, and homosexuality. (Liddle: in press)

\section{References}

Anderson, Benedict. 1983. Imagined Communities: Reflections on the Origin and Spread of Nationalism. London \& New York: Verso.

_. 1996. "'Bullshit!' S/he Said: the Happy, Modern, Sexy, Indonesian Married Woman as Transsexual." In Fantasizing the Feminine in Indonesia, edited by Laurie J. Sears, 27094. Durham \& London: Duke University Press.

Bahroin. S., Drs. 1993. Panduan Praktis Mempelajari Nagham (Seni Baca Al-Qur'ân) [Practical guide for the study of melodies (for the Art of Reciting the Qur'ân]. Jakarta: Lembaga Pengajaran Privat SMFT IAIN Syarif Hidaytullah Jakarta.

Capwell, Charles. 1995. "Contemporary Manifestations of Yemeni-Derived Song and Dance in Indonesia." Yearbook for Traditional Music 27:76-89. 
Danielson, Virginia. 1991. "Artists and Entrepreneurs: Female Singers in Cairo during the 1920s." In Women in Middle Eastern History: Shifting Boundaries in Sex and Gender, edited by Nikke R. Keddie and Beth Baron, 292-309. New Haven \& London: Yale University Press.

. 1997. The Voice of Egypt: Umm Kûlthum, Arabic Song, and Egyptian Society in the Twentieth Century. Chicago: University of Chicago Press; Cairo: American University in Cairo Press.

Denny, Frederick M. 1985. "The Great Indonesian Qur'ân Chanting Tournament" William and Mary: The Alumni Gazette Magazine 54:33-37.

- 1988. "Qur'ân Recitation Training in Indonesia: A Survey of Contexts and Handbooks." In Approaches to the History of the Interpretation of the Qur'ân, edited by Andrew Rippen, 288-306. Oxford: Clarendon Press.

. 1989. "Qur'an Recitation: A Tradition of Oral Performance and Transmission." Oral Tradition 4(1-2):5-26.

Djajadiningrat-Nieuwenhuis, Madelon. 1992. "Ibuism and Priyayization: Path to Power?" In Indonesian Women in Focus, edited by Elsbeth Locher-Scholten and Anke Niehof, 4351. Leiden Kitlv Press.

Federspiel, Howard M. 1994. Popular Indonesian Literature of the Qur'ân. Ithaca: Cornell Modern Indonesia Project, Southeast Asia Program (Publication no. 72).

Gaunt, Kyra D. 1997. "What are the Drums Saying, Bwana?" Paper presented at the Fourth Conference of Feminist Theory and Music, University of Virginia, 7 June 1997.

Geertz, Clifford. 1960. The Religion of Java. Chicago: University of Chicago Press.

Lee, Tong Soon. 1999. "Technology and the Production of Islamic Space: The Call to Prayer in Singapore." Ethnomusicology 43(1):86-100.

Nelson, Kristina. 1985. The Art of Reciting the Qur'ân. Austin: University of Texas Press.

Pemberton, John. 1994. On the Subject of "Java." Ithaca: Cornell University Press.

Pratt Walton, Susan. 1996. "Heavenly Nymphs and Earthly Delights: Javanese Female Singers, Their Music and Their Lives." Ph.D. dissertation, University of Michigan.

The Qur'ân. 1991. (Arabic Text with a New Translation.) Translated and with an introduction by Muhammad Zafrulla Khan. Brooklyn: Olive Branch Press.

Schwarz, Adam. 1994. A Nation in Waiting: Indonesia in the 1990s. Sydney: Allen and Unwin.

Sears, Laurie J., ed. 1996. Fantasizing the Feminine in Indonesia. Durham \& London: Duke University Press.

Sells, Michael A. 1999. Approaching the Qur'an: The Early Revelations. Ashland, OR: White Cloud Press (with accompanying compact disc of recitations by various reciters including Maria Ulfah).

Shalihah, Khadijatus, M.A. 1983. Seni Baca Al-Qur'an dan Qiraat Tujub di Indonesia. Jakarta: Penerbit; Pustaka Alhusna.

Sutton, R. Anderson. 1989. "Identity and Individuality in an Ensemble Tradition: The Female Vocalist in Java." Women and Music in Cross Cultural Perspective, edited by Ellen Koskoff, 111-30. Urbana: University of Illinois Press.

- 1996. "Interpreting Electronic Sound Technology in the Contemporary Javanese Soundscape." Ethnomusicology 40(2):249-68.

Suryakusuma, Julia I. 1996. "The State and Sexuality in New Order Indonesia" In Fantasizing the Feminine in Indonesia, edited by Laurie J. Sears, 93-119. Durham \& London: Duke University Press.

Ulfah, Maria. 1996. "Hukum Melagukan Al-Qur'ân Secara Bersama” [Law of Singing the Qur'ân Together (in the manner of an ensemble)]. Media Al-Furqan Tabun 5:19-29.

van Zanten, Wim. 1989. Sundanese Music in the Cianjuran Style: Anthropological and Musicological Aspects of Tembang Sunda. Dordrecht, Holland \& Providence, RI: Foris. 